ISSN: 2085-0344 (Print)

ISSN: 2503-1864 (Online)

Journal homepage: www.ejournal.almaata.ac.id/literasi

Journal Email: literasi_stia@yahoo.com

\title{
Hubungan Pola Asuh Orang Tua terhadap Perkembangan Moral Siswa Kelas Tinggi di SD Negeri Cimpon Desa Tirtosari Kecamatan Kretek Kabupaten Bantul Tahun Ajaran 2014/2015
}

\author{
Khanif Maksum dan Shofia Khusni Winasih \\ PGMI Universitas Alma Ata \\ email:khanifmaksum@gmail.com
}

\begin{abstract}
This research is a survey research that takes sample from one population and uses questionnaire as the main data collection tool. The population in this study are 46 upper grades students and their parents Cimpon State Elementary School in Academic Year of 2014-2015. Samples are taken by using simple random sampling is which sample members of the population are taken randomly without any regard to the stratas in the population. Variables in this study consists of variable $X$ (Parenting pattern from upper grades students' parents) and variable $Y$ (Moral Development the upper grades students). The data collection techniques used in this research are observation, questionnaires, interviews, and documentation.

The results of this research shows that 3 parents (6.52\%) used uthoritarian parenting patern and all of their children, three children (100\%), showed less moral development. Parents who adopted democratic parenting were 43 parents (93.48\%) and most of their children, 23 children (53.5\%), showed adequate moral development and the rest of the children, 20 children (46.5\%), showed good moral development. Most of the upper grades students showed adequate moral development (23 children or 50\%); incontrast, children with less moral development were found as the smallest number (3 children or 6.5\%).

The result of Pearson correlation test obtained the value of X2 -0.380 and were significant at 0.009 ( $p$-value $<0.05$ ). This means that there is a relationship between parental patterns to children moral development in upper grades students in Cimpon Elementary School, Tirtosari Village, Kretek District, Bantul Regency in Academic Year of 2014/2015. In other words, this research hypothesis can be proven or accepted.
\end{abstract}

Keyword: Parenting Pattern, moral development.

\begin{abstract}
Abstrak
Jenis penelitian ini menggunakan penelitian survei, yaitu penelitian yang mengambil sampel dari satu populasi dan menggunakan kuisioner sebagai alat pengumpulan data yang pokok. Populasi dalam penelitian ini sebanyak 46 siswa dan orang Tua siswa Kelas tinggi di SD Negeri Cimpon Tahun Ajaran 2014-2015. Pengambilan sampel menggunakan simple random sampling yaitu pengambilan anggota sampel dari populasi dilakukan secara acak tanpa memperhatikan strata yang ada dalam populasi. Variabel dalam penelitian ini terdiri dari variabel X (Pola asuh orang tua siswa kelas Tinggi di SD Negeri Cimpon Tahun Ajaran 2014-2015) dan variabel Y (Perkembangan Moral Siswa kelas Tinggi di SD Negeri Cimpon Tahun Ajaran 2014-2015). Teknik pengumpulan data menggunakan observasi, angket, wawancara, dan dokumentasi.
\end{abstract}


Hasil analisis pola asuh otoriter sebanyak 3 orang (6.52\%) dan semua anaknya menunjukkan perkembangan moral yang kurang sebanyak 3 anak (100\%). Orang tua yang menerapkan pola asuh demokrasi sebanyak 43 orang (93.48\%) dan sebagian besar anaknya menunjukkan perkembangan moral yang cukup sebanyak 23 anak (53.5\%) dan sisanya anak dengan perkembangan moral yang baik sebanyak 20 anak (46.5\%). Perkembangan moral anak, sebagian besar siswa kelas tinggi memiliki perkembngan moral yang cukup sebanyak 23 anak (50\%) dan sebaliknya anak dengan perkembangan moral yang kurang ditemukan dalam jumlah terkecil sebanyak 3 anak (6.5\%).

Selanjutnya, hasil uji korelasi pearson diperoleh nilai $X^{2}$ hitung sebesar -0.380 dan signifikan pada 0.009 (p-value < 0.05). Artinya bahwa ada hubungan pola asuh orang tua terhadap perkembangan moral siswa kelas tinggi di SD Negeri Cimpon Desa Tirtosari Kecamatan Kretek Kabupaten Bantul tahun ajaran 2014/2015. Dengan kata lain, hipotesis penelitian ini dapat terbukti atau diterima.

\section{Keyword : Pola Asuh, Perkembangan Moral}

\section{PENDAHULUAN}

Moralitas dapat dipandang sebagai antitesis terhadap minat diri seseorang, atau sebagai bahan yang esensial dalam pertumbuhan dirinya, tergantung dari corak oreintasi yang bersangkutan terhadap moralitas itu. Dalam posisinya yang ekstrem, moralitas mungkin dipandang sebagai suatu penghambat terhadap berbagai hasrat diri yang bersifat antisosial namun nyata. Akan tetapi pada posisi ekstrem lain, moralitas itu dapat dipandang sebagai suatu arah yang paling aman dan paling menguntungkan dalam rangka pencerahan minat dirinya. ${ }^{1}$

Perkembangan moral merupakan hal yang sangat penting bagi perkembangan kepribadian dan sosial anak untuk menuju kedewasaanya. Masalah moral menjadi salah satu aspek penting yang perlu ditumbuhkembangkan dalam diri anak. Berhasil tidaknya penanaman nilai moral anak sangat menentukan baik buruknya perilaku moral seseorang pada masa selanjutnya, karena dengan adanya perkembangan moral ini, anak akan mengetahui bagaimana berpikir mengenai konsep benar dan salah, baik dan buruk, pantas dan tidak pantas, dan bagaimana mereka bertindak juga melalui suatu proses.

${ }^{1}$ William M. Kurtines \& Jacob L. Gerwit, Moralitas, Perilaku Mora, dan Perkembangan Moral, Terjem. M. I Soelaeman, (Jakarta: Penerbit Universitas Indonesi, 1992), hlm. 180.
Perkembangan moral tidak terlepas dari lingkungan keluarga. Keluarga merupakan lembaga pertama dalam kehidupan anak, tempat ia belajar dan menyatakan diri sebagai makhluk sosial. Dalam keluarga umumnya anak ada dalam hubungan interaksi yang intim. Keluarga memberikan dasar pembentukan kepribadian, tingkah laku, watak, moral dan pendidikan anak. $^{2}$ Keluarga sebagai kelompok masyarakat terkecil terbentuk oleh ikatan dua orang dewasa yang berlainan jenis kelamin, wanita dan pria serta anak-anak yang mereka lahirkan. Dalam kelompok ini, arus kehidupan di kemudikan oleh orang tua. Alam mempercayakan pertumbuhan serta perkembangan anak pada mereka. Keluarga yang ideal adalah keluarga yang dapat menjalankan peran dan fungsi dari keluarga dengan baik sehingga akan terwujud hidup yang sejahtera. Untuk dapat mewujudkan keluarga yang sejahtera, faktor dalam keluarga yang mempunyai peranan penting adalah penerapan pola asuh orang tua.

Secara naluri setiap anak akan menirukan perbuatan yang dilakukan oleh kedua orang tuanya, karena anak memiliki kebiasaan meniru yang kuat terhadap seluruh gerak dan perbuatan dari orang tua. Realitas yang demikian itu perlu mendapat perhatian tersendiri, karena

${ }^{2}$ Kartini Kartono, Peran Keluarga Memandu Anak, Cet.Ke-2, (Jakarta: Rajawali Press, 1992), hlm. 19 
perkembangan moral anak akan sangat ditentukan oleh kondisi dan situasi yang terdapat dalam keluarganya. Hal ini berkaitan dengan kedudukan keluarganya sebagai lingkungan yang pertama dan paling utama oleh anak. Dengan asumsi bahwa keluarga merupakan unit sosial terkecil yang memberikan pondasi primer bagi perkembangan anak, maka pola asuh orangtua yang diterapkan pada anak akan sangat berpengaruh pada perkembangan moralitasnya. Bila pola asuh yang diterapkan pada anak baik maka akan membentuk kepribadian anak yang baik pula, sedangkan bila orang tua salah menerapkan pola asuh akan berdampak buruk pada perkembangan moral anak.

Harapan dan keinginan orang tua terhadap anak-anaknya, memberi tugas dan tanggung jawab serta pemenuhan terhadap kebutuhan anak-anaknya, baik kebutuhan fisik maupun non fisik. Termasuk di dalamnya, dalam menanamkan nilai moral pada anak, agar anak memiliki pemahaman yang baik terhadap nilai dan norma yang akan membawa pengaruh baik terhadap moralitas anak sehingga mereka dapat hidup harmonis di lingkungannya.

Mengasuh dan membesarkan anak berarti memelihara kehidupan dan kesehatannya serta mendidiknya dengan penuh ketulusan dan cinta kasih. Secara umum tanggung jawab mengasuh anak adalah tugas kedua orang tuanya. Anak lahir dalam pemeliharaan orang tua dan dibesarkan dalam keluarga. Orang tua bertugas sebagai pengasuh, pembimbing, pemelihara, dan sebagai pendidik terhadap anak-anaknya. Setiap orang tua pasti menginginkan anakanaknya menjadi manusia yang pandai, cerdas dan berakhlakul karimah. Akan tetapi banyak orang tua yang tidak menyadari bahwa cara mereka mendidik membuat anak merasa tidak diperhatikan, dibatasi kebebasannya, bahkan ada yang merasa tidak disayang oleh orang tuanya. Perasaan-perasaan itulah yang banyak mempengaruhi sikap, perasaan, cara berpikir, bahkan kecerdasan mereka.

Berdasarkan paparan di atas, penulis merasa tertarik untuk membahas lebih lanjut masalah pola asuh orangtua yang ada di SD
Negeri Cimpon Desa Tirtosari Kecamatan Kretek Kabupaten Bantul, khususnya berkenaan dengan pola asuh yang berhungan dengan perkembangan moral siswa kelas tinggi yaitu kelas 4, 5 dan 6. Penulis memilih SD tersebut sebagai obyek penelitian dikarenakan melihat adanya pola asuh orang tua yang tidak mengetahui ataupun kurang paham mengenai perkembangan moral ankanya. Karena orang tua yang sering kali salah paham sehingga menyebabkan mereka tidak bijak dalam menanamkan nilai-nilai moral pada anak, dalam arti cara yang ditempuh sering tidak menggunakan prinsip-prinsip penanaman nilai moral sesuai dengan tahap perkembangan anak usiaa Sekolah Dasar. Selain itu, pola asuh orang tua di SD Negeri Cimpon juga kurang memahami pencapaian perkembangan anaknya yang berimbas pada permasalahan pada anak. Begitu juga dengan perkembangan moral anak yang sudah mulai memperihatinkan di era globalisasi sekarang ini seperti; perbuatan yang tidak mencerminkan perilaku akan usia Sekolah Dasar, sikap mudah tersinggung/marah, bicara porno dan tidak sopan, suka mengasingkan diri, tidak patuh pada aturan dan hilangnya sikap kepolosan anak yang sudah mencoba-coba mengikuti sikap orang remaja/dewasa. ${ }^{3}$

Perkembangan moral yang tidak bisa terlepas dari orang tua, juga dibenarkan oleh Ibu Rujirah, S.Pd selaku wali kelas 6 yang menemukan beberapa pesrta didiknya bertingkah laku kurang wajar dalam permasalahan sopan santun terhadap orang yang lebih dewasa, tidak bertanggung jawab dalam mentaati peraturan sekolah serta tingkah laku yang menyimpang yang seharusnya tidak pantas dilakukan seusia anak kelas $6 .{ }^{4}$ Begitu pula yang terjadi di kelas 5. Meskipun sebagian besar siswanya sudah bisa diterima secara peraturan, namun ada yang menjadi masalah di Kelas 5 ini. Ibu Indarti, S.Pd. mengatakan bahwa ada peserta didiknya yang tingkah lakunya berbeda dari yang lain.

${ }^{3}$ Hasil Observasi pada tanggal 19 Januari 2015 di SD N Cimpon

${ }^{4}$ Rujirah, Wali Kelas 6, Wawancara tanggal 9 Maret 2015 di SD N CIMPON

LITERASI, Volume VIII, No. 22017 | 
Dari yang mudah marah, tersinggung, berbicara kurang sopan terhadap orang tua juga tidak mau bergaul dengan teman-temannya (memilih untuk menyendiri). ${ }^{5}$ Lain halnya kelas 6 dan 5 , masalah perkembangan moral yang ada di kelas 4. Ibu Tumantini, S.Pd mengatakan bahwa siswanya ada yang menjadi masalah. Beliau mendapati siswanya yang mencuri jajan dikantin, ada juga yang siswa tidak bertanggung jawab (berangkat sekolah tidak disiplin), berpakaian tidak sesuai aturan atau ada juga yang kurang rapi, suka berbohong, mudah tersinggung sampai juga bicaranya yang tidak pantas untuk diucapkan sesuai tahap perkembangan bahasa anak kelas $4 .^{6}$

\section{METODE PENELITIAN}

Penelitian ini merupakan penelitian kuantitatif. Penelitian kuantitatif merupakan suatu penelitian yang analisisnya secara umum memakai analisis statistik dengan rumus prosentase untuk mengetahui pola asuh orang tua. Karenanya dalam penelitian kuantitatif pengukuran terhadap gejala yang diminati menjadi penting, sehingga pegumpulan data dilakukan dengan menggunakan daftar pertanyaan berstruktur (angket) yang disusun berdasarkan pengukuran terhadap variabel yang diteliti kemudian menghasilkan data kuantitatif. $^{7}$

Jenis penelitian yang digunakan dalam penelitian ini adalah jenis penelitian survei, yaitu penelitian yang mengambil sampel dari satu populasi dan menggunakan kuisioner sebagai alat pengumpulan data yang pokok. ${ }^{8}$

Desain penelitian yang digunakan dalam penelitian ini adalah metode deskriptif analisis yaitu berusaha mencari gambaran menyeluruh

${ }^{5}$ Indarti, Wali Kelas 5, Wawancara tanggal 9 Maret 2015 di SD N CIMPON

${ }^{6}$ Tumartini, Wali Kelas 4, Wawancara tanggal 9 Maret 2015 di SD N CIMPON

${ }^{7}$ Bambang Prasetyo dan Lina Miftahul Jannah, Metode Penelitian Kuantitatif, (Jakarta: PT Raja Grafindo Persada, 2005), Edisi 1, hlm. 184

${ }^{8}$ Masri Singarimbun dan Sofian Efendi, Metode Penelitian Survei, (Jakarta: LP3ES, 1995), Cet.Ke-2, hlm. 3 tentang data, fakta, peristiwa sebenarnya mengenai obyek penelitian. Penelitian deskriptif bermaksud membuat pemberian (penyandaraan) secara sistemaitika, faktual, dan aktual mengenai fakta-fakta dan sifat-sifat populasi tertentu. ${ }^{9}$

\begin{tabular}{|c|c|c|}
\hline $\begin{array}{c}\text { Pola Asuh Orang Tua } \\
\text { (Variabel X)Deces }\end{array}$ & $\mathrm{r}_{x y}$ & $\begin{array}{c}\text { Perkembangan Moral } \\
\text { (Variabel Y) }\end{array}$ \\
& &
\end{tabular}

Keterangan:

$\mathrm{r}_{x y}$ : Hubungan antara variabel $\mathrm{X}$ (Pola asuh orang tua) terhadap Variabel Y (Perkembangan Moral).

Gambar 1. Desain Penelitian

Kegiatan penelitian ini sebagai usaha untuk mencari ada tidaknya Hubungan Pola Asuh Orang Tua terhadap Perkembangan Moral Siswa Kelas Tinggi di SD Negeri Cimpon Kecamatan Kretek Kabupaten BantulTahun Pelajaran 2014/2015.

Teknik pengumpulan data dalam penelitian ini menggunakan 4 metode, yaitu: Observasi, Wawancara (Interview), Angket, Dokumentasi. Observasi dalam penelitian ini dilakukan untuk memperoleh gejala atau fenomena yang terjadi sebagai masalah tentang pola asuh orang tua dan perkembangan moral siswa yang ada di SD Negeri Cimpon untuk dikaji dan diselidiki lebih lanjut. Proses observasi tentang pola asuh dilakukan di tempat tinggal siswa SD Negeri Cimpon sedangkan perkembangan moral dilakukan disekolah dan dirumah siswa. Selain itu observasi juga digunakan untuk mencaridata tentang kondisi umum SD Negeri Cimpon Desa Tirtosari Kecamatan Kretek Kabupaten Bantul.

Wawancara dalam penelitian ini dilakukan untuk mencari informasi data lebih lanjut tentang apa yang belum diketahui dengan cara tanya jawab lisan. Proses wawancara dilakukan dengan mewawancarai Guru (wali kelas), Kepala Sekolah serta Orang tua siswa kelas tinggi di SD Negeri Cimpon Desa Tirtosari, Kecamatan Kretek Kabupaten Bantul. Sehingga

${ }^{9}$ Husaini Usman Purnomo Setiady, Metodologi Penelitian Sosial, (Jakarta: PT. Bumi Aksara, ), Cet Ke-2, hlm. 4 
data wawancara ini digunakan untuk menunjang lebih langsung tentang pola asuh orang tua serta perkembangan moral dan kondisi yang ada di SD Negeri Cimpon. Hasil data ini bisa digunakan sebagai penguat dari penelitian ini.

Proses penyebaran angket dalam penelitian ini dikirim secara langsung dan diisi oleh responden (Orang tua dan Siswa kelas tinggi yang ada di SD Negeri Cimpon) untuk mendapatkan data yang akan disajikan sebagai hasil penelitian.

Dokumentasi ini dilakukan untuk memperoleh data tentang struktur organisasi, visi misi, didirikannya SD Negeri Cimpon dan benda-benda tertulis lainnya, seperti buku, majalah, dokumen, notulen pertemuan dan sebagainya.

Untuk mengetahui hubungan pola asuh orang tua terhadap perkembangan moral siswa kelas tinggi, dilakukan dengan menggunakan instrumen skala likert. Skala likert digunakan untuk mengukur sikap, pendapat, dan persepsi orang atau sekelompok orang tentang fenomena sosial. ${ }^{10}$ Data yang diperoleh dengan menggunakan kuisioner, hasil analisisnya dipresentasikan dalam tabel analisis berdasarkan variabel pola asuh orang tua dan dapat dilihat pengaruhnya terhadap perkembangan moral siswa kelas tinggi di SD Negeri Cimpon Desa Tirtosari Kecamatan Kretek Kabupaten Bantul.

\section{HASIL DAN PEMBAHASAN}

Berdasarkan hasil penyebaran angket, peneliti dapat menyajikan beberapa data temuan lapangan antara lain: Uji keabsahan data yang digunakan dalam penelitian ini terdiri dari uji validitas dan uji reliabilitas. Pengujian dilakukan dengan menggunakan sofware SPSS I6,0 for Windows. Kuisioner berisikan 25 butir pernyataan yang menyangkut variabel bebas yaitu pola asuh orang tua dan untuk variabel terikat yaitu perkembangan moral berisikan 20 butir pernyataan. Uji validitas dilakukan dengan menggunakan program SPSS 16,0 For Windows dengan kreteria:

\footnotetext{
${ }^{10}$ Sugiyono, Metode Penelitian Pendidikan, (Bandung: Alfabeta, 2012), hlm. 134
}

- Jika $r_{\text {hitung }}>r_{\text {tabel }}$ maka pernyataan tersebut valid.

- Jika $r_{\text {hitung }}<r_{\text {tabel }}$ maka pernyataan tersebut tidak valid.

Semua butir pernyataan sebanyak 25 butir dengan sempel sebanyak 20 Orang, $r_{\text {tabel }}$ adalah sebesar 0,444 dapat dilihat bahwa nilai $r_{\text {hitung }}$ semuanya lebih besar dari nilai $r_{\text {tabel }}$ sehingga dapat disimpulkanbahwa 25 butir pernyataan tentang Pola Asuh Orang tua tersebut adalah valid. Dengan demikian, semua butir pertanyaan tersebut dapat digunakan sebagai angket untuk pengukuran variabel penelitian ini.

Selanjutnya semua butir pernyataan sebanyak 20 butir dengan sempel sebanyak 20 Orang, $r_{\text {tabel }}$ adalah sebesar 0,444 dapat dilihat bahwa nilai $r_{\text {hitung }}$ semuanya lebih besar dari nilai $r_{\text {tabel }}$ sehingga dapat disimpulkan bahwa 20 butir pernyataan tentang perkembangan moral tersebut adalah valid. Dengan demikian, semua butir pernyataan tersebut dapat digunakan sebagai angket untuk pengukuran variabel penelitian ini.

Uji Reliabilitas dalam penelitian ini menggunakan Cronbach Alpha dengan software SPSS 16.0 for Widows yaitu dengan cara klik Analyze lalu klik Scala lalu klik Reliability Analysis lalu masukkan data yang akan diolah kemudian klik OK. Kreteria pengambilan keputusannya adalah:

- Jika nilai $r_{\text {hitung }}>r_{\text {tabel }}$ maka item dapat dikatakan reliabel.

- Jika nilai $r_{\text {hitung }}<r_{\text {tabel }}$ maka item dapat dikatakan reliabel

- Jika Cronbach Alpha $\left(r_{11}\right)<0,60$ maka dinyatakan reliabel.

Uji Reliabilitas Variabel Pola Asuh Orang Tua menunjukkan bahwa 25 butir pernyataan tentang pola asuh orang tua,dengan tingkat signifikan 5\% dan sempel 20 Orang maka Cronbach Alpha $\left(r_{11}\right)>0,60$; sehingga dapat dikatakan bahwa semua butir pernyataan angket variabel pola asuh orang tua memenuhi syarat reliabel dan dapat disebarluaskan kepaada responden sebagai instrumen dalam penelitian ini. 
Uji Reliabilitas Variabel Perkembangan Moral Anak menunjukkan bahwa 20 butir pernyataan tentangperkembangan moral, dengan tingkat signifikan $5 \%$ dan sempel 20 Orang maka Cronbach Alpha $\left(r_{11}\right)>$ 0,60 ; sehingga dapat dikatakan bahwa semua butir pernyataan angket variabel pola asuh orang tua memenuhi syarat reliabel dan dapat disebarluaskan kepaada responden sebagai instrumen dalam penelitian ini.

Karakteristik Orang Tua Siswa SD Negeri Cimpon berdasarkan karakteristik pendidikan, sebagian besar orang tua berpendidikan dasar (tamatan SD - SMP) sebanyak 23 orang $(50 \%)$ dan sebaliknya orang tua yang berpendidikan tinggi ditemukan dalam jumlah terkecil sebanyak 3 orang (6,5\%). Berdasarkan karakteristik pekerjaan orang tua, sebagian besar orang tua bekerja sebagai buruh sebanyak 19 orang $(41,3 \%)$ dan sebaliknya orang tua yang bekerja sebagai guru ditemukan dalam jumlah terkecil sebanyak 1 orang saja $(2,2 \%)$.

Berdasarkan kelas, sebagian besar anak duduk di bangku kelas IV sebanyak 19 anak $(41,3 \%)$ dan sebaliknya anak yang duduk di bangku kelas $\mathrm{V}$ ditemukan dalam jumlah terkecil sebanyak 12 anak $(26,1 \%)$.

Berdasarkan umur anak, sebagian besar anak berumur 10 tahun sebanyak 17 anak (37\%) dan sebaliknya anak yang berumur 12,5 dan 14 tahun ditemukan dalam jumlah terkecil, masingmasing sebanyak 1 anak $(2,2 \%)$.

Hasil uji deskripstif terhadap variabel dalam penelitian ini menunjukkan bahwa berdasarkan variabel pola asuh orang tua, sebagian besar orang tua menerapkan tipe pola asuh demokrasi sebanyak 43 orang $(93,5 \%)$ dan sebaliknya orang tua yang menerapkan tipe pola asuh otoriter ditemukan dalam jumlah terkecil sebanyak 3 orang $(6,5 \%)$.

Selanjutnya, berdasarkan perkembangan moral anak, sebagian besar siswa kelas tinggi memiliki perkembngan moral yang cukup sebanyak 23 anak (50\%) dan sebaliknya anak dengan perkembangan moral yang kurang ditemukan dalam jumlah terkecil sebanyak 3 $\operatorname{anak}(6,5 \%)$.
Untuk mengetahui ada tidaknya hubungan antara pola asuh orang tua terhadap perkembangan moral anak pada siswa kelas tinggi, maka dilakukan pengujian statistik berupa uji korelasi pearson. uji korelasi pearson dalam penelitian ini menunjukkan bahwa orang tua yang menerapkan pola asuh otoriter sebanyak 3 orang $(6,52 \%)$ dan semua anaknya menunjukkan perkembangan moral yang kurang sebanyak 3 anak (100\%).

Orang tua yang menerapkan pola asuh demokrasi sebanyak 43 orang $(93,48 \%)$ dan sebagian besar anaknya menunjukkan perkembangan moral yang cukup sebanyak 23 anak $(53,5 \%)$ dan sisanya anak dengan perkembangan moral yang baik sebanyak 20 anak (46,5\%). (dibuktikan lampiran 12 rekapitulasi gabungan).

Selanjutnya, hasil uji korelasi pearson diperoleh nilai $\mathrm{X}^{2}$ hitung sebesar -0.380 dan signifikan pada 0.009 ( $\mathrm{p}$-value $<0.05$ ). Artinya bahwa ada hubungan pola asuh orang tua terhadap perkembangan moral siswa kelas tinggi di SD Negeri Cimpon Desa Tirtosari Kecamatan Kretek Kabupaten Bantul tahun ajaran 2014/2015. Dengan kata lain, hipotesis penelitian ini dapat terbukti atau diterima.

\section{Pola Asuh Orang Tua Siswa Kelas Tinggi di SD Negeri Cimpon Desa Tirtosari Kretek Bantul Tahun Ajaran 2014/2015}

Hasil dari uji deskriptif dengan cara pengambilan angket dengan jumlah populasi penelitian sebanyak 46 orang tua siswa kelas tinggi menunjukkan bahwa sebagian besar orang tua menerapkan tipe pola asuh demokratis sebanyak 43 orang $(93,5 \%)$ dan 3 orang $(6,5 \%)$ lainnya menerapkan tipe pola asuh otoriter. Kondisi demikian dapat dimungkinkan berhubungan dengan karakteristik orang tua, yang dalam hal ini adalah faktor pendidikan dan pekerjaan. Jika merujuk pada karakteristik pendidikan, meskipun sebagian besar orang tua berpendidikan dasar 23 orang (50\%), dengan tingkat pendidikan menengah sebanyak 20 orang $(43,5 \%)$ dan pendidikan tinggi ditemukan paling rendah sebanyak 3 orang $(6,5 \%)$. 
Pendidikan orang tua merupakan salah satu faktor yang dapat mempengaruhi pola asuh orang tua terhadap anak-anaknya. Kepedulian orang tua terhadap pengasuhan selain didasari faktor alami, juga karena faktor latar belakang pendidikannya, peranan pendidikan masingmasing orang tua sangatlah berpengaruh pada pemberian pengasuhan. Anak akan menjadi tumbuh dan berkarakter karena peranan pengasuhan orang tua yang mendasarinya. Perbedaan pendidikan yang dimiliki orang tua akan dapat terlihat pada kualitas hasil proses pengasuhan.

Pendidikan adalah suatu usaha untuk membimbing anak yang nantinya akan berguna untuk terjun ke masyarakat, seorang anak tidakselamanya akan mengalami pendidikan, sehingga dalam setiapperkembangannya perlu diasuh dan dibimbing agar mempunyai bekalyang cukup. Dalam kehidupan keluarga orang tua lah yang berperan sebagai pendidik yang pertama dan yang utama. Walau pada dasarnya orang tua mempunyai kemampuan yang berbeda-beda, hal ini dapat dipengaruhi oleh adanya pendidikan yang dicapainya. Sehingga tingkat pendidikan yang berbeda juga menunjukkan perbedaan kemampuan orang tua. Tingkat pendidikan orang tua yang berbeda jelas dapat mempengaruhi pengasuhan pada anaknya.

Dalam pelaksanaan pemberian pengasuhan seyogyanya orang tua tidak memaksakan kehendaknya, tetapi harus mengetahui apa yang dibutuhkan anak dan sesuai dengan usia perkembangan anak. Semua itu dimengerti oleh orang tua bila mereka mengerti dan peduli terhadap proses pengasuhan anak dalam keluarga. Pengasuhan orang tua yang diberikan pada anaknya bukanlah pengasuhan yang sifatnya sementara dan singkat, akan tetapi pengasuhan yang sifatnya interaksi antara orang tua dan anak secara langsung.

Peranan orang tua di sini sangatlah penting pada aktifitas pemberian polaasuh pada pembentukan akhlak dan dasartingkah laku yang nantinya akan berperan pada fase perkembangan selanjutnya, sehingga sangatlah penting wawasan dan pendidikan orang tua dalam upayapeletakan pola asuh di dalam keluarga.

Adapun bagi mereka yang berpendidikan lebih tinggi dalam memberikan pengasuhan pada anaknya seditik banyak berbeda dengan motivasi yang diberikanoleh orang tua berpendidikan rendah. Mereka tidak hanya memberikan pengetahuan secara sederhana tetapi juga memberikan perhatian penuh segalabentuk kebutuhan anak usia dini secara khusus sampai pada fasilitas yangdibutuhkan anaknya, hal ini disebabkan kesadaran mereka bahwa untuk menunjang keberhasilan perkembangan anaknya secara maksimal, tidak cukuphanya dengan memberikan pengasuhan dengan memenuhi salah satukebutuhannya saja. Tetapi perlu juga bimbingan dan pengasuhan yang lain. Selain penguasaan pengasuhan juga tak kalah pentingnya proses pengasuhan yang diberikan orang tua, ada yang menerapkan dengan pola asuh yang keras atau kejam, kasar dan tidak berperasaan, namun ada pula yang memakai pola lemah lembut dan kasih sayang (pola demokrasi). Ada pula yang memakai sistem militer yang apabila anaknya bersalah akan langsung akan diberikan hukuman dan tindakan tegas (pola otoriter). Bermacammacam pola asuh yang diterapkan orang tua ini sangat bergantung pada masing-masing karakter dasar orang tua dan bisa bergantung pula pada bentuk-bentuk penyimpangan perilaku anak. Namun demikian, semua kita kembalikan itu kepada individu masingmasing. Karena ada juga orang tua yang tingkat pendidikannya rendah tetapi punya kesadaran tinggi dalam memberikan pengasuhan. Bahwa dalam memberikan motivasi dan memfasilitasi dengan ketelatenan yang dipunyai orang tua akan dapat juga memberikan pola pengasuhan yang tidak kalah dengan mereka yang lebih tinggi tingkat pendidikannya, hal ini bisa dihitung kuantitasnya karena itu potensi dasar bawaan. ${ }^{11}$

${ }^{11}$ Galihjoko, Pengaruh Tingkat pendidikan orang tua terhadap pola asuh anak pada masyarakat. (2009) Dari http://www.indoskripsi.com. Diakses tanggal 2 Juni 2015 
Hal ini tentunya akan memberikan gambaran jika orang tua berpendidikan formal SMP tentunya memberikan efek bagi anakanaknya mengenai logika hidup dan gaya hidup lebih tidak jelas dan terkesan boros, kurang memiliki etika hidup yang normative, hal ini dikarenakan tingkat pengetahuan mengenai hidupitu sendiri kurang maksimal, namun semua itu kembali pada persoalan individu dari orang tua tersebut. Sedangkan untuk orang tua yang memiliki pendidikan SMA, tentunya memiliki taraf/standar pemikiran tentang kehidupan yang lebih baik, hal ini akan berkait pula dengan pola asuh dan orientasi masa depan bagi anak-anaknya dalam memberikan gambaran tantang masa depan. Dengan orang tua berpendidikan SMA minimal orientasi yang diberikan ke anak-anaknya juga berpendidikan SMAatau dimungkinkan lebih tinggi dari orang tuanya. Selanjutnya jika orang tua berpendidikan Sarjana, tentu lebih memberikanefek positif pada pola asuh yang diberikan bagi anak-anaknya, hal ini dilatarbelakangi oleh hasil keilmuan yang telah diperolah oleh orang tuanya semasastudi di perguruan tinggi, banyak persoalan kehidupan yang dikaitkan dengan teori yang selanjutnya diaplikasikan dalam kehidupan sehari-hari. Orang tua dengan predikat sarjana akan lebih berhati-hati dan selektifdalam memberikan berbagai kebutuhan baik psikis maupun psikologis bagitumbuh kembangnya anak-anak di kemudian hari. Orang tua dapat memilih pola asuh yang tepat dan ideal bagi anaknya. Orang tua yang salah menerapkan pola asuh akan membawa akibat buruk bagiperkembangan jiwa anak. Tentu saja penerapan orang tua diharapkan dapatmenerapkan pola asuh yang bijaksana atau menerapkan pola asuh yang setidak tidaknya tidak membawa kehancuran atau merusak jiwa dan watak seorang anak. ${ }^{12}$

Dengan demikian, perbedaan antara orang tua yang tingkat pendidikannya rendah dengan orang tua yang tingkat pendidikannya menengah

${ }^{12} \mathrm{Ibid}$, http://www.indoskripsi.com. Diakses tanggal 2 Juni 2015 dan mereka yang pendidikannya sarjana, baik dalam hal pengetahuan pengasuhan maupun langsung pemberian proses pengasuhan dapat mempengaruhi hasil pengasuhan, meskipun dalam hal ini tidak luput dari faktor lain. Orang tua yang mempunyai pendidikan yang lebih tinggilah yang lebih dapat memberikan pengasuhan lebih baik secara penguasaan teori dan prakteknya dalam pengasuhan, sehingga mereka diharapkan menjadi anak yang dapat bersosialisasi dengan baik di rumah maupun di lingkungannya diwaktu masa yang akan datang. Setelah memahami betapa pentingnya peran orang tua dalam usaha pemberian pengasuhan dalam upaya pencapaian perkembangan secara maksimal yang berujung pada pembinaan pribadi anak yang ungggul, diharapkan semakintinggi tingkat pendidikan orang tua semakin luas dalam memberikan motivasi dan stimulus, bimbingan, perhatian dan pembinaannnya, tentunya hal ini biladibandingkan dengan orang tua yang berpendidikan rendah.

Pekerjaan orang tua juga merupakan salah satu faktor yang berhubungan dengan pemberian pola asuh terhadap anak-anaknya. Hasil penelitian yang menunjukkan bahwa responden didominasi oleh orang tua yang bekerja sebagai buruh. Meskipun demikian, sebanyak $39,1 \%$ orang tua berstatus sebagai ibu rumah tangga. Ibu rumah tangga yang lebih banyak menghabiskan waktu dan aktivitasnya di dalam rumah dapat menjadi salah satu faktor positif dalam menerapkan pola asuh yang baik kepada anak-anaknya. Orang tua khususnya ibu merupakan orang pertama, utama dan yang terdekat dengan anak-anaknya. Orang tua merupakan pendidik yang pertama dan utama dalam memberikan pengasuhan kepada anakanaknya. Dilihat dari waktu untuk membagi waktu antara pekerjaan dengan pola asuh, maka dapat dikatakan bahwa ibu yang bekerja di luar rumah mempunyai waktu yang relatif sedikit dibandingkan ibu yang tidak bekerja atau berstatus sebagi ibu rumah tangga. ${ }^{13}$

${ }^{13}$ Hanif, Pendidikan Keluarga. (2005). Diambil dari http://HeruFerdi.Blogspot.com diakses 2 Juni 2015 


\section{Perkembangan Moral Siswa Kelas Tinggi di SD Negeri Cimpon Desa Tirtosari Kretek Bantul Tahun Ajaran 2014/2015}

Hasil dari uji deskriptif dengan cara pengambilan angket dengan jumlah populasi penelitian sebanyak 46 siswa kelas tinggi menunjukkan bahwa sebagian besar siswa/anak yang duduk di bangku kelas tinggi sekolah dasar memiliki perkembangan moral yang cukup sebanyak 23 anak (50\%), baik sebanyak 20 anak $(43,5 \%)$ dan kurang sebanyak 3 anak $(6,5)$.

Kondisi tersebut dapat dimungkinkan berhubungan dengan karakteristik diri siswa, dalam hal ini adalah umur dan tingkatan kelas. Orangtua tidak boleh memaksakan kehendaknya dalam pelaksanaan pemberian pengasuhan kepada anak-anaknya, tetapi harus mengetahui apa yang dibutuhkan anak dan sesuai dengan usia perkembangan anak. Siswa yang duduk di kelas tinggi bangku sekolah dasar dengan usia yang sebagian besar adalah 10 tahun, dapat dikatakan dalam kondisi yang serba terampil dan mulai adanya kekritisan. Orang tua mulai memberikan batasan yang konsisten berupa hal yang dapat dilakukan dan tidak boleh dilakukan. ${ }^{14}$

Dengan memahami hal tersebut, sebaiknya orang tua memberikan pendidik terbaik kepada anak dengan menanamkan nilai-nilai kehidupan yang baik padamasa ini kepada anak. Perilaku, sikap dan komitmen orang tua akan menjadi teladan dan sumber yang akan ditiru oleh anak-anak. Peranan orang tua di sini sangatlah penting pada aktifitas pemberian pola asuh pada anaknya pada dasarnya orang tua adalah pembentuk akhlak dan dasar tingkah laku yang nantinya akan berperan pada fase perkembangan selanjutnya, sehingga sangatlah penting wawasan dan pendidikan orang tua dalam upaya peletakan pola asuh di dalam keluarga. ${ }^{15}$

\footnotetext{
${ }^{14}$ Heru Ferdi, Pendidikan Keluarga.(2010). Diambil dari http://HeruFerdi.Blogspot.com diakses 2 Juni 2015.

${ }^{15}$ Godam 64. Jenis/Macam Tipe Pola Asuh Orang tua Pada Anak \& Cara Mendidik/Mengasuh Anak Yang Baik. (2008) Diambil dari http://organisasi.org/jenismacamtipe-pola-asuh-orangtua-pada-anak-cara-mendidik-
}

\section{Hubungan Pola Asuh Orang Tua Terhadap Perkembangan Moral Siswa Kelas Tinggi di SD Negeri Cimpon Desa Tirtosari Kecamatan Kretek Bantul Tahun Ajaran 2014/2015}

Hasil dari uji hipotesis dengan cara pengambilan angket dengan jumlah populasi penelitian sebanyak 46 orang tua siswa dan 46 siswa kelas tinggi menunjukkan bahwa terdapat hubungan pola asuh orang tua dengan perkembangan moral kelas tinggi di SD Negeri Cimpon Desa Tirtosari Kecamatan Kretek Kabupaten Bantul Tahun Ajaran 2014/2015.

Hal ini dibuktikan dengan cara menganalisis hubungan pola asuh orang tua terhadap perkembangan moral siswa kelas tinggi di SD Negeri Cimpon, dengan uji korelasi pearson yang diperoleh nilai $\mathrm{X}^{2}$ hitung sebesar -0.380 dan signifikan pada 0.009 ( $p$-value $<$ 0.05 ). Artinya bahwa ada hubungan pola asuh orang tua terhadap perkembangan moral siswa kelas tinggi di SD Negeri Cimpon Desa Tirtosari Kecamatan Kretek Kabupaten Bantul tahun ajaran 2014/2015. Dengan kata lain, hipotesis penelitian ini dapat terbukti atau diterima.

Dijelaskan lebih lanjut bahwa pola asuh adalah bentuk pengasuhan orang tua untuk menanamkan disiplin pada anaknya yang pada akhirnya akan membentuk kepribadian dan perilaku anak. Sebagai gambaran, efek pengasuhan otoriter, antara lain anak mengalami inkompetensi sosial, sering merasa tidak bahagia, kemampuan komunikasi lemah, tidak memiliki inisiatif melakukan sesuatu, dan kemungkinan berperilaku agresif. Anak dari orang tua yang otoriter sering kali tidak bahagia, ketakutan, minder ketika membandingkan diri dengan orang lain, tidak mampu memulai aktivitas, dan memliki kemampuan komunikasi yang lemah, serta sering berperilaku agresif. ${ }^{16}$

Pola pengasuhan demokratis memberikan efek berupa anak mempunyai kompetensi sosial percaya diri, dan bertanggung jawab secara sosial. Juga tampak ceria, bisa mengendalikan diri dan mandiri, berorientasi pada prestasi,

mengasuh-anak-yang-baik. diakses 2 Juni 2015 ${ }^{16} \mathrm{Ibid}$, Hlm. 217 
mempertahankan hubungan ramah dengan teman sebaya, mampu bekerja sama dengan orang dewasa, dan mampu mengatasi stres dengan baik. Anak dari orang tua yang demokratis ceria, bisa mengendalikan diri dan mandiri, dan berorientasi pada prestasi, mereka cenderung untuk mempertahankan hubungan yang ramah dengan teman sebaya, bekerja sama dengan orang dewasa, dan bisa mengatasi stres dengan baik. ${ }^{17}$

\section{KESIMPULAN}

Berdasarkan uraian di atas, dapat disimpulkan beberapa hal sebagai berikut:

Pola asuh orang tua kelas tinggi di SD Negeri Cimpon Desa Tirtosari Kecamatan Kretek Kabupaten Bantul tahun ajaran 2014/2015 dalam penelitian ini memiliki 2 prosentase antara pola asuh Demokratis dan Otoriter. Tingkat prosentase pola asuh tertinggi yaitu orang tua yang menerapkan tipe Demokratis 93,5\% (43 orang), sedangkan tingkat prosentasepola asuh terendah yaitu orang tua yang menerapkan tipe Otoriter $6,5 \%$ (3 orang). Hasil prosentase tersebut dibuktikan dengan hasil uji deskriptif yang didapat dari hasil olahan data pada pengisian angket oleh orang tua siswa kelas tinggi.

Perkembangan Moral siswa kelas tinggi di SD Negeri Cimpon Desa Tirtosari Kecamatan Kretek Kabupaten Bantul tahun ajaran 2014/2015 dalam penelitian ini, tingkat prosentase tertinggi yaitu memiliki perkembangan moral yang cukup sebanyak 23 anak (50\%), baik sebanyak 20 anak $(43,5 \%)$ dan perkembangan moral yanag kurang sebanyak 3 anak $(6,5 \%)$. Hasil prosentase tersebut dibuktikan dengan hasil uji deskriptif yang didapat dari hasil olahan data pada pengisian angket oleh siswa kelas tinggi.

Ada hubungan pola asuh orang tua terhadap perkembangan moral siswa kelas tinggi di SD Negeri Cimpon Desa Tirtosari

${ }^{17}$ Christiana Hari Soetjiningsih, Perkembangan Anak. (Jakarta: Prenada Media Group. 2012), hlm.216
Kecamatan Kretek Kabupaten Bantul tahun ajaran 2014/2015. Dibuktikan dengan hasil uji korelasi pearson diperoleh nilai $\mathrm{X}^{2}$ hitung sebesar -0.380 dan signifikan pada 0.009 (p-value $<0.05$ ).

\section{DAFTAR PUSTAKA}

Bambang Prasetyo dan Lina Miftahul Jannah, Metode Penelitian Kuantitatif, (Jakarta: PT Raja Grafindo Persada, 2005), Edisi 1

Christiana Hari Soetjiningsih,

Perkembangan Anak. (Jakarta: Prenada Media Group. 2012)

Husaini Usman Purnomo Setiady, Metodologi Penelitian Sosial, (Jakarta: PT. Bumi Aksara, )

Imam Ghozali, Aplikasi Analisis Multivariete Dengan Program SPSS, cetakan IV, (Semarang:Undip, 2006)

Kartini Kartono, Peran Keluarga Memandu Anak, Cet.Ke-2, (Jakarta: Rajawali Press, 1992)

Masri Singarimbun dan Sofian Efendi, Metode Penelitian Survei, (Jakarta: LP3ES, 1995)

Rambat Lupiyoadi dan A. Hamdani, Manajemen Pemasaran Jasa, (Jakarta: Salemba Empat, 2006), Cet ke-2

Sugiyono, Metode Penelitian Pendidikan, (Bandung: Alfabeta, 2012)

Sugiyono, Statistika untuk penelitian, (Bandung: CV. Alfabeta, 2010)

Suharismi Arikunto, Prosedur Penelitian Suatu Pendekatan Praktek, (Jakarta: Reneka Cipta, 2002)

Suharismi Arikunto, Prosedur Penelitian Suatu Pendekatan Praktek, (Jakarta: PT. Reneka Cipta, 2004)

Sutrisno Hadi, Metode Reseach, (Yogyakarta: Andi Offset, 1992), Jilid 2

William M. Kurtines \& Jacob L. Gerwit, Moralitas, Perilaku Mora, dan Perkembangan Moral, Terjem. M. I Soelaeman, (Jakarta: Penerbit Universitas Indonesi, 1992) 